\title{
ELEMEN PENGAMBILAN KEPUTUSAN DALAM PROSES KEPERAWATAN
}

Inayah Husna Sibarani / inayahhusna08@gmail.com

\section{LATAR BELAKANG}

Instalasi Gawat Darurat (IGD) merupakan unit pelayanan yang didirikan oleh rumah sakit untuk memberikan pelayanan gawat darurat. Pasien yang datang ke IGD merupakan pasien yang membutuhkan pertolongan cepat dan tepat sesuai dengan kondisi klinis yang dialaminya (Kementerian Kesehatan Republik Indonesia, 2009).

Hubungan perawat klien adalah dasar dari praktik keperawatan yang berfokus pada pasien (patient centered care). Keterlibatan pasien merupakan inti dari proses keperawatan, sehingga partisipasi pasien dalam proses keperawatan menjadi penting dalam penentuan kualitas dan efektifitas dalam pelayanan asuhan keperawatan. Membina hubungan ini didasarkan pada hubungan yang percaya, menghormati dan hubungan profesianal dengan mengedepankan nilai etik dan disiplin profesi.

Penilaian dan keputusan klinis sangat dibutuhkan untuk mendapatkan kualitas pelayanan yang optimal. Pemberian asuhan keperawatan harus berdasarkan nilai-nilai dan etika yang dianut oleh klien dan nilai-nilai profesional asuhan keperawatan. Mengkombinasikan nilai profesional, etik dan nilai yang di anut klien akan meningkatkan pelayanan, identifikasi kebutuhan dan masalah keperawatan lebih sistematis sehingga meningkatkan pemahaman klien dalam pengambilan keputusan asuhannya (Doheni. 1992, Potter. 2005, Jan florin. 2007).

Membuat keputusan merupakan bagian dari kehidupan kita sehari-hari baik secara individu ataupun secara kelompok, terutama dalam suatu organisasi. Pengambilan keputusan mempunyai arti penting bagi maju atau mundurnya suatu organisasi. Pengambilan keputusan yang tepat akan menghasilkan suatu perubahan terhadap organisasi ke arah yang lebih baik, namun sebaliknya pengambilan keputusan yang salah akan berdampak buruk pada roda organisasi dan administrasinya.

Proses pengambilan keputusan dalam praktik klinik keperawatan dipahami sebagai serangkaian keputusan yang dibuat oleh perawat dalam interaksinya dengan pasien mengenai jenis pengamatan yang akan dilakukan dalam situasi yang di alami 
klien (pengkajian keperawatan), perumusan diagnosa keperawatan, rencana tindakan keperawatan yang harus diambil, tindakan keperawatan yang akan diambil serta evaluasi (Dianan Catarina. 2009, Jan Florin. 2007, Mehee, 2014).

\section{METODE}

Kajian ini menggunakan metode kualitatif, metode ini bersifat memberikan penjelasan dengan membuat analisis. Proses pengkajian ini lebih menggunakan landasan teori dengan mengumpulkan data, bereksplorasi bebas yang telah disimpulkan dari berbagai sumber-sumber, yaitu buku, majalah, koran, jurnal print maupun jurnal online bertema perencanaan keperawatan. Saya membaca dari berbagai referensi berupa buku, jurnal print maupun jurnal online. Melalui metode ini kita dapat memahami pentingnya pengambilan keputusan, sehingga dengan mudah mengetahui rencana tindakan keperawatan apa yang akan selanjutnya dilakukan. Kemudian, mengetahui bahwa pengambilan keputusan yang tepat akan menghasilkan suatu perubahan ke arah yang lebih baik.

\section{HASIL}

Berdasarkan hasil, mengambil atau menetapkan keputusan adalah suatu proses yang dilaksanakan berdasarkan pengetahuan dan informasi yang ada dengan harapan sesuatu akan terjadi.
Keputusan dapat diambil dari alternatifalternatif keputusan yang ada. Ada tiga aspek yang berperan dalam analisa keputusan yaitu kecerdasan, persepsi dan falsafah. Menggunakan ketiga aspek tersebut membuat model, selanjutnya menentukan nilai kemungkinan, menetapkan nilai pada hasil yang diharapkan, serta menjajaki prefensi terhadap waktu dan resiko, maka untuk sampai pada suatu keputusan diperlukan logika.

Terdapat beberapa proses atau tahapan dalam mengambil suatu keputusan atau membuat keputusan dari berbagai pandangan, yaitu:

Handoko, menjelaskan bahwa proses dasar pembuatan keputusan rasional mencakup tahapan: 1) Pemahaman dan perumusan masalah, 2) Pengumpulan dan analisa data yang relevan, 3) Pengembangan alternatif-alternatif, 4) Evaluasi alternative alternatif, 5) Pemilihan alternatif terbaik, 6) Implementasi keputusan, dan 7) Evaluasi hasil-hasil keputusan.

Johanes Supranto, memaparkan langkah-langkah pengambilan keputusan sebagai berikut: 1) Rumuskan/definisikan persoalan keputusan, 2) Kumpulkan informasi yang relevan, 3) Cari alternatif tindakan, 4) Lakukan analisis alternatif yang fisibel, 5) Pilih alternatif terbaik, dan 
6) Laksanakan keputusan dan evaluasi hasilnya.

Siagian, mengemukakan terdapat tujuh langkah yang dapat ditempuh dalam pengambilan keputusan, yaitu: 1) Mengetahui hakekat masalah yang dihadapi, dengan perkataan lain mendefinisikan masalah yang dihadapi dengan setepat-tepatnya,

2) Mengumpulkan fakta-fakta dan data yang relevan, 3) Mengolah fakta-fakta dan data tersebut, 4) Menentukan beberapa alternatif yang mungkin ditempuh, 5) Memilih cara pemecahan dari alternatif yang telah diolah dengan matang, 6) Memutuskan tindakan yang hendak dilakukan, dan 7) Menilai hasil-hasil yang diperoleh sebagai akibat dari keputusan yang telah diambil.

\section{PEMBAHASAN}

Keputusan (decision) secara harfiah berarti pilihan (choice). Pilihan yang dimaksud di sini adalah pilihan dari dua atau lebih kemungkinan, atau dapat dikatakan pula sebagai keputusan dica-pai setelah dilakukan pertimbangan dengan memilih satu kemung-kinan pilihan. Seperti yang diungkapkan oleh Gito Sudarmo, bahwa keputusan terkait dengan ketetapan atau penentuan suatu pilihan yang diinginkan.
Bagaimanan perawat dalam mengambil keputusan klinis? Pengambilan keputusan keperawatan dilakukan pada semua tahap proses keperawatan. Sehingga seorang perawat harus mampu berpikir ktitis, berkomunikasi dengan baik sebagai suatu elemen penting dalam pengaambilan keputusan klinis, sehingga terjadi pembelajaran berkelanjutan bagi pasien sehingga meningkatkan tingkat kemandirian pasien.

Definisi di atas mengandung pengertian, dalam keputusan yaitu: (1) ada pilihan atas dasar logika atau pertimbangan; (2) ada beberapa alternatif yang harus dipilih salah satu yang terbaik; dan (3) ada tujuan yang ingin dicapai dan keputusan itu makin mendekatkan pada tujuan tersebut.

Setelah dipahami pengertian keputusan, selanjutnya dikutipkan pendapat para ahli mengenai pengertian pengambilan keputusan. Menurut Steiner pengambilan keputusan didefinisikan sebagai sua-tu proses manusiawi yang didasari dan mencakup baik fenomena individu maupun sosial, didasarkan pada premis nilai dan fakta, menyimpulkan sebuah pilihan dari antar alternatif dengan maksud bergerak menuju suatu situasi yang diinginkan. Pengertian ini menunjukkan bahwa pengambilan keputusan merupakan suatu proses pemilihan alternatif terbaik dari beberapa alternatif secara sistematis untuk 
ditindak lanjuti (digunakan) sebagai suatu cara pemecahan masalah.

Terkait dengan fungsi, maka tujuan pengambilan keputusan dapat dibedakan: (1) tujuan yang bersifat tunggal. Tujuan pengambilan keputusan yang bersifat tunggal terjadi apabila keputusan yang dihasilkan hanya menyangkut satu masalah, artinya bahwa sekali diputuskan, tidak ada kaitannya dengan masalah lain dan (2) tujuan yang bersifat ganda. Tujuan pengambilan keputusan yang bersifat ganda terjadi apabila keputusan yang dihasilkan menyangkut lebih dari satu masalah, artinya keputusan yang diambil itu sekaligus memecahkan dua (atau lebih) masalah yang bersifat kontradiktif atau yang bersifat tidak kontradiktif.

Keputusan yang diambil akan dapat diasumsikan baik bila telah memenuhi ketentuan-ketentuan sebagai berikut: 1) keputusan diambil sebagai pemecahan masalah yang dihadapi; 2) sedapat mungkin cepat dan tepat; 3) bersifat rasional, artinya dapat diterima akal sehat terutama bagi para pelaksana yang nantinya bertanggung jawab atas keputusan tersebut; 4) bersifat praktis dan pragmatis, artinya dapat dilaksanakan dengan kemampuan yang ada; 5) berdampak negatif seminim mungkin; 6) menguntungkan banyak pihak demi kelan-caran kerja dan arah tujuan yang hendak dicapai; 7) keputusan yang diambil dapat dievaluasi untuk masa yang akan datang.

Dengan demikian di dalam mengambil sebuah keputusan, ha-rus memperhatikan hal-hal sebagai berikut: 1) dalam proses pe-ngambilan keputusan tidak terjadi secara kebetulan; 2) pengambilan keputusan dilakukan secara sistematik, yaitu: tersedianya sumber-sumber untuk melaksanakan keputusan yang akan diambil, kua-lifikasi tenaga kerja yang tersedia, falsafah yang dianut organisasi, situasi lingkungan internal dan eksternal yang akan mempengaruhi administrasi dan manajemen di dalam organisasi; 3) masalah harus diketahui dengan jelas; 4) pemecahan masalah harus didasarkan pada fakta-fakta yang terkumpul dengan sistematis; 5) keputusan yang baik adalah keputusan yang telah dipilih dari berbagai alter-natif yang telah dianalisa secara matang.

Apabila pengambilan keputusan tidak didasarkan pada kelima hal di atas, akan menimbulkan berbagai masalah: 1) Tidak tepatnya keputusan; 2) tidak terlaksananya keputusan karena tidak sesuai dengan kemampuan organisasi baik dari segi manusia, uang mau-pun material; 3) ketidakmampuan pelaksana untuk bekerja karena tidak ada sinkronisasi antara kepentingan organisasi dengan orang-orang di dalam organisasi tersebut; 4) timbulnya penolakan terhadap keputusan. 
Beberapa konsep yang digunakan untuk menggambarkan berpikir kritis dalam keperawatan adalah penalaran klinis, perumusan diagnostik, pengambilan keputusan, penilaian, dan pemecahan maslah. Menurut penelitian yang dilakukan oleh Panggabean, 2019 kemampuan berfikir kritis perawat dalam pengambilan keputusan klinis berhubungan erak dengan kemampuan berfikir kritis perawat dengan nilai $\mathrm{p}=0,026$ dan juga menurut Khairina, 2018 pengalaman kerja mempunyai hubungan erat dengan kemampuan pengambilan keputusan klinis dengan nilai p value 0,012 .

Berpikir kritis digambarkan sebagai "sebuah proses, tujuan untuk membuat keputusan yang masuk akal tentang apa yang harus percaya dan apa yang harus dilakukan". Pengambilan keputusan klinis adalah sebuah proses yang melibatkan kedua penalaran diagnostik dan penilaian klinis. Tindakan dalam ini tindakan diarahkan sebagai proses refleksi dari perawat maupun pasien (Jan Florin, 2007).

\section{Dokumentasi adalah proses} keperawatan. Sehingga kualitas dokumentasi keperawatan merupakan cermin dari keberhasilan asuhan dalam proses keperawatan (Jan Florin 2007). Dokumentasi keperawatan meliputi permusan diagnosa keperawatan, tujuan, rencana tindakan, implementassi dan evaluasi. Sesuai dengan standar disiplin profesi pendokumentasian dan pelaksanaan tersebut harus sesuai dengan standar yang telah ditetapkan yaitu harus memenuhi standar sebagai berikut:

1. Pengkajian Keperawatan dilakukan berdasarkan standart pengkajian yang digunakan dalam rumah sakit yang bersangkutan dan dilakukan dokumentasi sesuai dengan standart yang ada.

2. Diagnosa adalah sebuah keputusan dan sekaligus sebagai hipotesis terhadap masalah yang dihadapi oleh pasien selama dilakukan perawatan dirumah sakit. Data pasien harus divalidasi/reasesment setiap hari, sehingga diagnose menyesuaikan data yang ditemukan pada hari itu karena diagnosa keperawatan adalah respon dimana kemungkinan respon setiap hari berubah. Jika respon pasien berubah maka diagnosa keperawatanpun akan berubah pula.

3. Perencanaan merupakan suatu langkah sitematis untuk mengatasi masalah keperawatan sesuai dengan tujuan yang diharapkan. Jika diagnosa berubah maka intervensi harus mengikuti diagnosa yang muncul dan terdokumentasi.

4. Implementasi Keperawatan merupakan tindakan yang dilakukan oleh seoarang perawat 
berdasarkan intervensi/rencana

keperawatan.

Dalam

pelaksanaannya harus ada Standar

Prosedur Operasional (SPO) atau

panduan dalam melakukan

implementasi.

5. Evaluasi adalah validasi terus menerus menerus terhadap pencapaian tujuan keperawatan berdasarkan diagnosa yang diambil.

Kualitas suatu rumah sakit sudah tentu tergantung juga pada kualitas pelayanan keperawatan yang diberikan oleh perawat. Karena selain perawat merupakan jumlah tenaga kesehatan yang paling banyak di rumah sakit, perawat juga merupakan tenaga kesehatan yang paling lama berinteraksi dengan pasien dan yang paling dekat dengan pasien (Nursalam, 2014). Oleh karena itu kualitas pelayanan keperawatan merupakan suatu hal yang sangatlah penting untuk diperhatikan oleh pihak rumah sakit.

\section{PENUTUP}

Seorang perawat harus mempunyai keberanian untuk mengambil keputusan dan memikul tanggung jawab atas akibat dari resiko yang timbul sebagai konsekuensi dari keputusan yang telah diambilnya. Pengambilan keputusan adalah suatu pendekatan yang sistematis terhadap hakekat suatu masalah yang difokuskan untuk memecahkan masalah secepatnya dimana individu harus memiliki kemampuan berfikir kritis dengan menggunakan pendidikan dan pengalaman yang berharga yang cukup efektif dalam pemecahan masalah. Dalam pengambilan keputusan perawat harus mempertimbangkan segala aspek, baik dari pasien itu sendiri, keluarga pasien, tenaga kesehatan lain, dan psiko, sosial, dan cultural yang diterapkan, Perawat juga harus ikut membantu klien ataupun keluarga klien dalam mengambil keputusan yang berhubungan dengan kesehatan klien. 


\section{DAFTAR PUSTAKA}

Anwar, Herson. (2014). Proses Pengambilan Keputusan untuk Mengembangkan Mutu Madrasah. Jurnal Pendidikan Islam. Vol. 8, No 1, 37-56.

Deniati, dkk. (2018). Pengaruh Berfikir Kritis Terhadap Kemampuan Perawat Pelaksana Dalam Melakukan Asuhan Keperawatan di Rumah Sakit Hermina Bekasi Tahun 2016. Jurnal Kesehatan Holistik, 12(1), 21-24.

Erawantini, F. \& Wibowo, N. S. 2019. Implementasi Rekam Medis Elektronik dengan Sistem Pendukung Keputusan Klinis. Jurnal Teknologi dan Terapan. 6 (2): 75-78.

Hariawan, Peggy. Kholil, Muhammad. Gadissa, A A N. ANALISA PENGAMBILAN KEPUTUSAN PADA PENENTUAN CAIRAN ANTISEPTIK TANGAN YANG TERBAIK DENGAN METODE ANALYTICAL HIERARCHY PROCESS (AHP). Jurnal PASTI. Volume IX No 2, $203-219$.

Khairina, Ilfa. Malini, Hema. Huriani, Emil. (2018). FAKTOR-FAKTOR YANG BERHUBUNGAN DENGAN PENGAMBILAN KEPUTUSAN PERAWAT DALAM KETEPATAN TRIASE DI KOTA PADANG. Indonesian Journal for Health Sciences. Vol.02, No.01, 1-6.

Khurniawan, Dimas. Wulandari, Deasy. Dimyati, Mohammad. (2017). e-Journal Ekonomi Bisnis dan Akuntansi, Volume IV (1), 44-48.

Mariana, Dina. (2019). HUBUNGAN KUALITAS PELAYANAN KEPERAWATAN RAWAT INAP DENGAN PROSES PENGAMBILAN KEPUTUSAN PASIEN UNTUK MEMILIH RUMAH SAKIT. Jurnal Ilmiah Multi Science Kesehatan. Vol 10, No 2, 145-126.

Pashar, Imran. Dwiyantoro, Luky. (2020). Pengaruh Empowerment Terhadap Pengambilan Keputusan Perawat: Kajian Literature Review. JOURNAL OF HOLISTIC NURSING SCIENCE. Vol. 7 No. 2, 124-132.

Rahayu, Candra Dewi. Mulyani, Sri. (2020). PENGAMBILAN KEPUTUSAN KLINIS PERAWAT. Jurnal Ilmiah Kesehatan. 1-11.

Santoso, Budi. (2010). KUNCI KEBERHASILAN PROSES PENGAMBILAN KEPUTUSAN. MANAJERIAL. Vol. 8, No. 16, 28 - 33.

Simamora, R. H. (2019). Menjadi perawat yang: CIH'HUY. Surakarta: Kekata Publisher. 